\title{
CITY LIFE IN
}

\section{JAPAN}





\title{
CITY LIFE IN JAPAN A Study of a Tokyo Ward
}

\author{
BY R. P. DORE
}

UNIVERSITY OF CALIFORNIA PRESS

Berkeley and Los Angeles 1963 
University of California Press

Berkeley and Los Angeles

California

(C) R. P. Dore 1958

Printed in Great Britain 